\title{
The European Refugee Crisis: transitioning the EU from state-centric 'kingdoms' to a federalist system of multi- level governance
}

\author{
Stephen Mighton - Queen's University
}

\section{Introduction}

In an era where European integration has become increasingly questioned and where Euroscepticism battles the objectives envisioned by the Maastricht Treaty of 1992, the European Union (EU) desperately needs to revitalize its project of unification if its hopes to survive. Events of the last decade, such as the sovereign debt crisis, the global financial crisis, and the evolving refugee crisis, have challenged the efficacy of the EU and have seemingly undermined its legitimacy as a regulatory body. Taken individually, these crises pose a potent threat to the success of European integration and to the enlargement of member state unification. Most recently, the ongoing refugee crisis has created a sense of disunion within the EU giving way to a state of calamity as successive European efforts have failed at resolving this issue. Reeling from civil conflict and political turmoil, individuals from various regions, most notably Africa, the Middle East, and South Asia, have fled the dangers and uncertainties of their homes in order to seek refuge within neighbouring European countries. This arduous and sudden development has prompted commentators, such as former Greek finance minister Yanis Varoufakis, to claim that the solidarity of the EU is being threatened at a level not seen since the migrant crisis of 1945 during the Second World War. ${ }^{1}$

Although the EU has attempted to enhance the cooperation between member states and EU institutions in immigration and asylum policies, the effectiveness in dealing with the current crisis has been abysmal. In reaction to the surge of asylum-seekers ${ }^{2}$, individual member states have sought to pursue responsive measures that are isolationist in nature, choosing this option over more cohesive, cooperative efforts more often than not. ${ }^{3}$ By applying the divergent integration theories of 'multi-level governance' and 'state-centrist model' as discussed by Gary Marks et $\mathrm{al}^{4}$, it can be shown that EU member states have opted for a state-centric, or intergovernmental, approach in favour of a multi-level governance effort in their attempts to resolve the crisis. This paper will

\footnotetext{
${ }^{1}$ Martin Farrer, "Yanis Varoufakis: Europe is being broken apart by the refugee crisis," theguardian, November 23, 2015, Web, accessed November 29, 2015, http://www.theguardian.com/world/2015/nov/23/yanis-varoufakis-europe-is-being-broken-apart-byrefugee-crisis.

${ }^{2}$ Asylum-seekers are defined by Paul Baker and Costas Gabrielatos as someone who has fled persecution in their homeland and exercised the legal right to apply for asylum or the right to live in the country which they have arrived (Baker and Gabrielatos 2008, 15).

${ }^{3}$ Elspeth Guild et al., "The 2015 Refugee Crisis in the European Union," Center for European Policy Studies no. 332, September 2015, Web, accessed November 29, 2015, https://www.ceps.eu/system/files/CEPS\%20PB332\%20Refugee\%20Crisis\%20in\%20EU 0.pdf.

${ }^{4}$ Gary Marks, Liesbet Hooghe, and Kermit Blank, "European Integration from the 1980s: State-Centric v. Multi-level Governance," Journal of Common Market Studies 34, no. 3 (1996): 341-378, DOI: 10.1111/j.1468-5965.1996.tb00577.x.
} 
attempt to show how state-centric conflict resolution within the EU is ineffective and in some cases, detrimental to European integration, making the argument that it has in fact exacerbated the current refugee crisis. It will be shown that the only sufficient response able to resolve the crisis is by fostering a multi-level governance method of cooperation that seeks to establish a common response to refugees ${ }^{5}$ across all member states. In doing so, it is argued that states must be willing to forgo some of their sovereignty in order to shift a majority of authority onto the EU so as to produce a federalist structure that increases competences and the capability to organize this multilevel response. The scope of this paper is limited to asylum policy and as such, does not argue for a complete federalist overhaul of the $\mathrm{EU}$, as this would certainly be rejected by member states in many policy areas. Rather, it is shown how the transition to a federalist approach in dealing with the refugee crisis may be the only effective resolution.

\section{State-Centric vs. Multi-Level Governance Theories}

Among the dominant theories of European integration, two of the prevailing concepts are state-centric and multi-level governance. Whereas the former seeks to explain integration based on the deliberation and bargaining between state executives (as states are the ultimate decisionmakers); the latter argues that decision-making is shared between various actors at different levels rather than being monopolized by the state, and is in fact a process of state decentralization by sharing control over outcomes. ${ }^{6}$ State-centrists attempt to conceptualize EU membership as a means of strengthening state sovereignty, and the EU as simply being an arena that facilitates bargains and interactions between member state governments. ${ }^{7}$ Realistically however, the emergence of transnational municipal networks across Europe and the increasing interdependence of European nations in the face of globalization, suggests that a multi-level governance model is a better way of understanding politics in the EU. The EU has developed into a system of multiple sources of authority that include European, national, and subnational levels of governance. ${ }^{8}$ Rather than confining the EU to a definition solely concerned with nation states, Kristine Kern attempts to provide a more holistic and pragmatic illustration of EU governance:

The concept of multi-level governance can be read in a narrow way as shifting competencies between local, national and supranational governmental institutions, or it can take into account not only traditional methods of public regulation by the state, but also the entire range of actions and institutions which provide order (including public-private partnerships, non-state actors and so on). Authority has not simply shifted upwards to European institutions, it has become dispersed across multiple territorial levels and among a variety of private and public actors. This includes the transfer of authority from the national to the sub-national level because in many European countries government has become increasingly decentralized and local competencies expanded. ${ }^{9}$

Multi-level governance is a much clearer description of contemporary relationships and dynamics within the EU and provides a superior description of European integration than state-

\footnotetext{
${ }^{5}$ Baker and Gabrielatos mark the distinction of refugee from asylum-seeker as someone whose asylum application has been successful, having proved they would face persecution back home. Thus, refugees and asylum-seekers are extremely similar in their definition; the only difference being that a refugee's claim of persecution is recognized as valid (Baker and Gabrielatos 2008, 15).

${ }^{6}$ Ibid, 345-346.

${ }^{7}$ Ibid, 342.

${ }^{8}$ Kristine Kern and Harriet Bulkeley, "Cities, Europeanization and Multi-Level Governance: Governing Climate Change through Transnational Municipal Networks*," Journal of Common Market Studies 47, no. 2 (2009): 311. ${ }^{9}$ Ibid.
} 
centric theory does. State-centrists seem incapable of recognizing the realities of recent EU enlargement and the ensuing treaties that significantly transferred levels of power and real decision-making authority onto EU institutions. Therefore, the state-centrist model appears to be outdated and incapable of applying itself to modern discussions of EU governance. Similarly it may not be able to induce productive analysis regarding policy negotiations. Ultimately, in the context of the refugee crisis, state-centrist theory will be able to define the singular, isolationist approaches of member states but will be ineffective of proposing a viable solution to this issue. Multi-level governance on the other hand, will be able to identify the responses of various actors, notably the EU and various member states, and can strongly argue that a higher degree of multi-level cooperation is necessary if the refugee crisis is to be resolved.

\section{EU Asylum Policies and Practices beyond the Cold War}

The Geneva Convention on the Status of Refugees that was codified in 1951 served as the foundation for European asylum policy until it was restructured in 1967 to include refugees from non-European states. ${ }^{10}$ Within this convention, refugees were protected under a shroud of liberalist universalism. Asylum was thus attainable regardless of race, gender, or religion, and was a universally practiced policy by western European states following the Second World War. ${ }^{11}$ Throughout the Cold War, perceptions surrounding the Soviet Union, and of communism more generally, began to broaden the definition of refugee. This definition included those who suffered violations of their civil and political freedoms which, when combined with the sentiments of WWII, created a broad acceptance and common implementation of asylum policy across Europe. ${ }^{12}$ Rather than outlining how to deal with large influxes of refugees, this policy was tailored specifically for individuals and included a strict right to 'non-refoulement,' or the inability of the state to send a refugee back to a country where their right to life and liberty would be threatened. ${ }^{13}$ Clearly then, early examples of European refugee policies were focused on the refugees themselves and were unanimously implemented in a concerted effort between states to mitigate conflict. Although these efforts were largely successful, the relatively high demand for immigrant labour in the post-war period may in part explain these successes. ${ }^{14}$ What is important to note here however, is that for several decades, there was an absence of immigrant-driven internal conflict within Europe? The lack of internal tension was the result of states working collectively in applying the same guidelines to their responses and actions.

Moving into the 1970s and 1980s however, endogenous and exogenous factors began to put pressure on Europe, considerably straining their ability to handle the integration of asylumseekers. Internally, the recession of 1973 that severely increased unemployment across Europe, as well as several instances of disrupted race relations, most notably in the UK, forced states to curb their immigration policies and restrict the avenues available to asylum seekers. ${ }^{15}$ Furthermore, the transition into the 1980s and 1990s saw several civil conflicts beyond European borders including

\footnotetext{
${ }^{10}$ Christina Boswell, "Values and the Asylum Crisis," International Affairs 76, no. 3 (2000): 539, http://www.jstor.org/stable/2625953.

${ }^{11}$ Ibid, 540.

12 Ibid.

${ }^{13}$ Ibid, 541.

${ }^{14}$ Ibid, 542.

${ }^{15}$ Ibid, 541.
} 
from within the former Yugoslavia. These episodes of strife blended with the removal of restrictions on refugees originating from the former Soviet bloc to produce a significant expansion of the number of people seeking asylum within Europe. ${ }^{16}$ The hands of national decision-makers became tied, making it near impossible for European countries to avoid conflict and societal unrest due to the particularly complex asylum crisis that began to emerge. This led to asylum-seeking becoming a central theme in European policy resulting in the creation of several treaties, most importantly the Nice Treaty and the Lisbon Treaty. Both of these treaties sought to establish a common legislative framework for handling immigrants while also officially granting power to EU institutions so that they could influence decision-making outcomes. ${ }^{17}$ Additionally, the Maastricht Treaty established a legal basis for adopting a common asylum and immigration process, and the Amsterdam Treaty set out minimum standards for granting refugee status. ${ }^{18}$ The treaties also provided a framework for member states to ratify these rules and for the EU to regulate them. ${ }^{19} \mathrm{As}$ the project of integration intensified and the power of the EU grew, it is clear that there was a transition in the way that the EU attempted to resolve interstate crises. With regards to immigration policy and prior efforts at dealing with European asylum crises, there was a shift from intergovernmentalism to a multi-level governance model wherein decisions were shared across the institutional spectrum of the EU. This model has remained in place throughout the first decade and a half of the Twenty First Century. For the most part, multi-level decision-making is a central component of EU action, while generating important effects on border control, asylum, and irregular migration. ${ }^{20}$

\section{Current Responses to the Refugee Crisis: The "Fortress" Approach}

The current crisis has largely been influenced by a combination of the tyrannical Syrian leader Bashar al-Assad and a growing terrorist network, the Islamic State, wreaking havoc within Syria and surrounding Middle Eastern regions. The EU itself has recognized the unprecedented rate at which people continue to flock to Europe. The president of the European council Donald Tusk declared it as a challenge not seen in decades, including those experienced in wars close to the region's frontiers. ${ }^{21}$ It appears however, that the European response has been characterized by a contradiction between a moral obligation to endorse the human rights of refugees, reflecting the liberal universalism of past policies, and a stark incompetence to administer a comprehensive policy for its member states. Whereas the treaties of the EU call for common protocols in dealing with asylum-seekers, what has actually transpired has been an intergovernmental campaign between member states who have engaged those seeking asylum through isolationist policies.

\footnotetext{
${ }^{16}$ Christina Boswell, “The 'external dimension' of EU immigration and asylum policy," International Affairs 79, no. 3 (2003): 621.

${ }^{17}$ Petra Bendel, "Asylum and Migration Policy," in Policies within the EU Multi-Level System, edited by Hubert Heinelt and Michele Knodt (Germany: Nomos, 2011): 371.

${ }^{18}$ Boswell, "Values," 542-543.

${ }^{19}$ Ibid.

${ }^{20}$ Christina Boswell and Andrew Geddes, "Studying Migration and Mobility in the European Union," in Migration and Mobility in the European Union (New York: Palgrave Macmillan, 2011): 7-8.

${ }^{21}$ Chris McGreal, "Donald Tusk defends European response to 'unprecedented' refugee crisis," theguardian, September 29, 2015, Web, accessed November 30, 2015, http://www.theguardian.com/world/2015/sep/29/donald-tusk-defends-european-values-united-nations.
} 
Commenting on these nonaligned methods, Lukas Kaelin notes that virtually all of the EU member nations have been affected differently by the crisis' complexity ${ }^{22}$, causing each state to pursue different approaches based on how severe their situation was. ${ }^{23}$ In particular, Kaelin mentions the methods undertaken by Greece, Hungary, Germany, France, the Netherlands, and Austria. He explains how the continual failure of the EU to enforce a common asylum system has left nation states no other option but to handle the situation as individuals. Moreover, by referencing unequal rules of migrant distribution and the unsuccessful attempts of the EU to convince its member nations to adopt a quota system ${ }^{24}$, Kaelin highlights the inability of the EU to utilize its authority and become an influential decision-making partner in the situation. He suggests that the EU has become irrelevant in certain aspects of the crisis noting that countries have bypassed the collaborative stage in favour of domestic solutions to the problem. His major concern involves the separate ways in which different countries are attempting to deter and even get rid of asylum-seekers because the EU is incapable of controlling the actions of states. ${ }^{25}$ Clearly, Kaelin's opinion conforms to that of a state-centrist in that he believes the policy outcomes regarding the refugee crisis are determined by individual member nations who ignore the authority of supranational institutions. He claims that, "In reaction to the flow of migrants, Europeans have focused on reinforcing national borders." 26 This illustrates how national governments have internalized the decision-making process and have effectively shut the EU out. Kaelin's perspective of European integration therefore falls in line with the core principles of the state-centric model.

A large number of states have in fact taken what I call a 'fortress' approach to dealing with the situation, which involves defensive or protectionary methods. They have attempted to barricade their respective borders hoping that it will stall those seeking asylum to the point where they turn elsewhere for help. Hungary has not only sealed off its borders with Serbia and Croatia by constructing a fence, it is also arresting people for trying to cross the border, successfully eliminating any route into the country. ${ }^{27}$ Similarly, Austria has imposed stringent security checks on those seeking refuge within the country making it extremely difficult for asylum-seekers to obtain protection. ${ }^{28}$ Additionally, Poland, the Czech Republic, and Slovakia have each only accepted a small number of refugees, with the latter being criticized for stating that it would only accept those of Christian faith. ${ }^{29}$ There has also been much discussion about the potential deployment of armed forces along several countries' borders. This would complement the already utilized water cannons and tear gas, forcefully repelling those fleeing violence and other forms of persecution

\footnotetext{
${ }^{22}$ UNHCR The UN Refugee Agency, “2015 UNHCR regional operations profile - Europe,” UNHCR Global Appeal 2015 Update, 2015, http://www.unhcr.org/5461e5f80.html.

${ }^{23}$ Lukas Kaelin, "Europe's Broken Borders," Foreign Affairs, September 2, 2015, accessed November 30, 2015, http://www.foreignaffairs.com/articles/western-europe/2015-09-02/europes=broken-borders.

${ }^{24}$ Lukas Kaelin, "Europe's Broken Borders,” 2015.

${ }^{25}$ Ibid.

${ }^{26}$ Ibid.

27 "Reactions to Refugee Crisis May Violate States' International Legal Obligations," International Justice Resource Center, November 25, 2015, Web, accessed November 30, 2015, http://www.ijrcenter.org/2015/11/25/reactions-to-refugee-crisis-may-violate-states-international-legalobligations/.

${ }^{28}$ Ibid.

${ }^{29}$ Luke Graham, "How Europeans have reacted to migrant crisis," CNBC, September 8, 2015, http://www.cnbc.com/2015/09/08/how-europeans-have-reacted-to-migrant-crisis.html.
} 
hoping to find safety within the EU. ${ }^{30}$ Collectively then, the reaction of many states has been to create a 'fortress' whereby they reinforce their borders to barricade, limit, and expel refugees from entering into their territory in order to protect the nation's integrity and interests of native citizens.

The imagery that arises from this parallels that of a king in his castle digging a moat and stationing knights around his kingdom to protect himself from peasant uprisings. These European 'fortresses' have done nothing to resolve the current crisis. Instead, they have made life indefinitely worse for those already fleeing horrific situations, have created longer and more dangerous routes (often by sea), and have significantly intensified issues associated with shelter and living conditions in other member nations. Essentially, these European 'strongholds' have exacerbated the crisis by prioritizing state interests over the lives of hundreds of thousands of people. By pursuing isolationist, state-centric responses to the crisis, member states have created a pattern of integovernmentalism. This pattern has diminished solidarity by uprooting the best practices of asylum policy established in various EU treaties and through its fragmentation of European integration as a whole. It has also brought to light questions surrounding European values and the future of the EU; specifically, can the project of EU integration survive if its constituents cannot be swayed to adopt a humanitarian conscience consistent with the liberal values the EU itself was founded on? It appears as though self-interested member states would rather shrink into themselves through kingly citadels and militarism than embrace the liberal universalism set out in the constitution of the EU.

Not all individual responses have been negative however. A handful of member states have actually proven to be successful in generating positive results. In particular, Germany and Sweden granted the largest number of Syrians asylum from 2012-2014 (39,965 and 31,771 respectively) in addition to refugees who were granted temporary protection (an extra 27,035 and 7,465 respectively). ${ }^{31}$ Each country has also made further commitments to accepting more refugees in the near future. The highly state-centric response witnessed throughout this crisis has therefore not produced negative results across the board. In a small number of cases, individual nations have been able to foster an effective response and provide haven for thousands of refugees. More recently, the EU, led by German Chancellor Angela Merkel, proposed a deal with Turkey attempting to limit the number of refugees entering Europe so as to reduce the burden on certain European states. ${ }^{32}$ However, the logic and future success of this proposal remains under scrutiny. Turkey not only borders the civil war-torn country of Syria, Turkish officials have also commented on the sheer logistical difficulty in accommodating the increased inflow, making conditions for asylum-seekers volatile and dangerous. ${ }^{33}$

\footnotetext{
${ }^{30}$ Gwynne Dyer, "Europe's Refugee Crisis: The Good, the Bad and the Ugly," The Sydney Morning Herald, September 3, 2015, Web, accessed December 1, 2015, http://www.smh.com.au/comment/eu-response-to-migrantcrisis-ranges-from-generosity-to-panic-20150903-gje39e.html.

${ }^{31}$ Nicole Ostrand, "The Syrian Refugee Crisis: A Comparison of Responses by Germany, Sweden, the United Kingdom, and the United States," Journal of Migration and Human Security 3, no. 3 (2015): 269-271.

${ }^{32}$ Krishnadev Calamur, "The Steady Trickle of Refugee Deaths in the Mediterranean," The Atlantic, February 8 , 2016, Web, accessed March 11, 2016, http://www.theatlantic.com/international/archive/2016/02/refugeesdrowning/460419/.

${ }^{33}$ Ibid.
} 


\section{Making the Case for Federalism}

Once enough pressure is applied on a king by a peasant uprising who challenge his effectiveness and legitimacy to govern, he has no choice - other than death - but to hand over his kingdom to the people, therein relinquishing his 'fortress.' This metaphor resonates with the current refugee crisis unfolding in Europe. Many individual nation states have acted as 'kings' or as isolationist decision-makers hiding behind the 'fortress' of their borders, and are conceivably indifferent to the human suffering of individuals fleeing persecution. These state-centric reactions have stifled the ability of the EU to put forward an effective solution and have increased the pressure on both cooperative member states as well as on asylum-seekers themselves. The severity of this crisis cannot be understated. The human suffering, tragic losses of thousands of people, and disregard of states in upholding their duty to protect human rights, all serve as justification for an urgent resolution. In 2015 alone, more than 1,800,000 people sought refuge in the EU, about $1,012,000$ of whom travelled across seas in order to reach safety. ${ }^{34}$ These sea escape routes present an extremely treacherous journey for asylum-seekers. Often by overcrowded boats, displaced families sail across the Mediterranean in small wooden boats; a travel plan that resulted in the death of more than 3,770 migrants in 2015. ${ }^{35}$ As of February 5, 374 asylum seekers have died in 2016, mostly from drowning, adding to the already high death toll. ${ }^{36}$ If a solution is not found soon, tension may reach a breaking point within the EU, leading to a rapid unravelling of European integration and quite possibly to the dissolution of the EU as a whole. It is quite clear that intergovernmentalism has not presented itself as a viable solution, and the case studies of several individual EU member states have proven that there is a dire need for a new approach.

Many analysts have called for a more cohesive response to the problem involving a consolidation of authority within EU institutions. This is exactly what Europe needs; a system of multi-level governance with an emphasis on the decision-making capability of EU institutions. Rather than a system of many independent 'kingdoms,' the EU needs to resemble a federalist system whereby the EU is the highest level of authority and has near complete jurisdiction in matters of asylum-seeking. Federalism is described as,

[...] a euphemism for at least four partially incompatible preferences: "diffusion" of authority from national to relatively local government units, "centralization" of national authority, "separation" of national and state authority, and "empowerment" of both state and national governments. ${ }^{37}$

Similarly, federalism facilitates the importance of federal power in restraining the power of state governments. Due to the overlapping of governmental power, in order to ensure successful implementation of policy it is necessary to have a strong central authority,

First, federal institutions play a coordinating role in the exercise of concurrent state authority [...] Second, some grants of exclusive or preemptive power to the federal government serve both a vertical allocation function and $a$ horizontal conflict avoidance function (emphasis added). ${ }^{38}$

34 "Migrant Crisis: Migration to Europe explained in several charts," $B B C$ News, March 4, 2016, Web, accessed March 13, 2016, http://www.bbc.com/news/world-europe-34131911.

${ }^{35}$ Ibid.

${ }^{36}$ Krishnadev Calamur, "The Steady Trickle of Refugee Deaths in the Mediterranean," The Atlantic, February 8 , 2016, Web, accessed March 11, 2016, http://www.theatlantic.com/international/archive/2016/02/refugeesdrowning/460419/.

${ }^{37}$ Allan Erbsen, “Horizontal Federalism,” Minnesota Law Review 93.2 (2008-2009): 499-500.

${ }^{38}$ Ibid, 504.

Federalism-e 
From these connotations, it is clear to see why a federal approach to the refugee crisis would be effective. First, although the member states would retain some of their power, the central governing agencies of the EU would be given a centralized level of authority and would be empowered to wield influence. Second, EU institutions would be better suited to reel noncompliant states into line with common asylum policies, while also acting as a preventative mechanism to horizontal conflicts. Of course, this system would not be ideal for the functioning of the Union as a whole, as member states would most likely reject a federalist overhaul and ensuing concessions of authority. However, it would be effective in this specific policy field.

As George Ross indicates, throughout the history of the EU, intergovernmentalism and the lack of a strong central arbiter, has been the crux of fragmentation;

When crises occurred, it was because member states stopped cooperating. When things stagnated, it was because member states preferred to go their own separate ways.[...] When 'rationality and governance' fell out of phase, meaning when member states had not yet understood that there were new needs for Europeanization, cooperation could not happen and crisis followed. ${ }^{39}$

Moreover, as the project of European integration faces adversity and skepticism, a big project viewed as vitally important by all citizens that the EU alone could confront, may steer integration back on course. Maybe more importantly, a task like this could ward off a return to the decentralization of state-centrism; because if the EU has no response to the real challenges people face, they will turn toward national responses. ${ }^{40}$

\section{Potential Explanations of European State-Centrism}

If we are to fully understand why countries have seemingly circumvented EU institutions in favour of isolationist policies, it is pertinent to explore several potential causes for this behaviour. One such causal factor is that a majority of asylum-seekers reach small, often times overwhelmed countries first and are expectant that they will be granted asylum. Many of the landing sites for Syrian refugees are Mediterranean countries such as Greece and Italy and, according to the Dublin III Regulation,

[...] the first Member State an asylum-seeker entered is responsible for examining their application for international protection. This means that an asylum-seeker who moves to another state will be transferred back to the Member State at the EU's external borders [...] As a consequence of the Dublin rules, Member States on the EU's external borders literally form the front line for asylum applications, at the same time as coming under great pressure from irregular migrants. The overload on some Member States' asylum systems has led to both poor conditions for asylum-seekers (unjustified detentions, mistreatment, etc.) and to lower rates of asylum being granted. ${ }^{41}$

Related to the Dublin rules ${ }^{42}$, another factor influencing the responses of member states is the enduring effects of the European sovereign debt and global financial crises that have affected

\footnotetext{
${ }^{39}$ George Ross, "Flight of the Member States," in The European Union and Its Crises: Through the Eyes of the Brussels Elite (New York: Palgrave Macmillan, 2011): 61.

${ }^{40}$ Ibid, 108-109.

${ }^{41}$ Piotr Batowski, Eva-Maria Poptcheva, and Detelin Ivanov, "EU migratory challenge: Possible responses to the refugee crisis," European Parliament Research Service, September 2015, http://www.europarl.europa.eu/RegData/etudes/BRIE/2015/568312/EPRS BRI(2015)568312 EN.pdf.

${ }^{42}$ In order to understand how Dublin rules complicate the refugee crisis, see Jan-Paul Brekke and Grete Brochmann's article "Stuck in Transit: Secondary Migration of Asylum Seekers in Europe, National Differences,
} 
the economies of all European states. The financial reality in welcoming refugees, which requires an initial investment of public funds ${ }^{43}$, may ward off countries who still suffer under debt payments and weak economies from conforming to the EU's common asylum policies. Most recently, the attacks in Paris and a growing concern over terrorism has increased the reluctance of states to accept refugees based on religious identification. This event has significantly heightened isolationism as it has forced countries close to the attack such as Belgium, Italy, and France to close and securitize its borders in order to coordinate efforts to apprehend the perpetrators. It has also given partial justification to those countries already skeptical of accepting refugees such as Poland, Latvia, the Czech Republic, and Slovakia. These events have allowed them to incite demands for further restrictions, utilizing loose, xenophobic linkages of the Muslim identity of many refugees to terrorism as their source of justification. ${ }^{44}$ Terrorism continues to challenge the solidarity of the EU and may explain, in part, why certain nations are hesitant to adopt an asylum program, as well as why some nations continually reconsider their refugee commitments.

Lastly, there is an institutional factor that may contribute to the skepticism of embracing an EU-led common approach. There is currently no EU-wide asylum status enshrined within the Lisbon Treaty, which instead sets out a common system. In other words, the EU's asylum system allocates responsibility for the processing of asylum applications to individual member states, while also ensuring the state provides protection when asylum is granted. ${ }^{45}$ Thus, a state is not legally required to protect emigrants unless they grant them asylum. As mentioned above, many states have denied this privilege to a large number of asylum-seekers, if any at all. These factors may explain why in most cases, individual states perceive the burdensome policies of the EU as counter-beneficial and instead, opt for methods that better suit their own capabilities and interests.

\section{Conflict and Divergence within the EU Multi-Level System}

Although on the surface, the very idea of multi-level governance seems superior to statecentrism and well-suited for a region like the EU, it has not functioned flawlessly and has faced a number of challenges. Member states are in fact legally bound by the various EU treaties to implement community law in an efficient manner, but as Simona Milio explains:

and the Dublin Regulation." Brekke and Grete explain that Member States agreed to the implementation of the Dublin Regulation in order to foster EU harmonization and to reduce difference between countries through supranational legislation. Since its inception, it has been revised twice, most recently in 2013 (Dublin III) but still remains problematic and disruptive to the common European asylum system as a whole. The authors make note of several deviations from the Dublin rules, in particular Norwegian officials not forcing those who arrived in Greece but fled to Norway to return to Greece for processing. However, they are critical of how the Dublin rules complicate an already dire situation, in many instances 'binding' refugees to the harsh conditions of the country they arrive in, while also placing disproportionate pressure on a handful of national governments (Brekke and Brochmann 2015, 150).

${ }^{43}$ Philippe Legrain, “The Disintegration of Europe," Social Europe, October 20, 2015, Web, accessed December 1, 2015, http://www.socialeurope.eu/2015/10/the-disintegration-of-europe/.

44 Joanna Plucinska, “The Paris Attacks Have Put Europe's Refugee Crisis Under Renewed Scrutiny," Time, November 16, 2015, Web, accessed December 1, 2015, http://time.com/4114009/paris-attacks-migrant-crisisrefugees-eu/.

${ }^{45}$ Bakowski et al., "EU migratory challenge," 2-3. 
In the EU there is an explicit division of competences in relation to the implementation of policies between the EU institutions and the Member States, with the EU Commission responsible for monitoring the correct transposition and application of Community law while responsibility for the execution of policies lies with the Member States. Policy implementation is in general a delicate phase of the policy-making process, more so in the EU, where deviations in the implementation phase from the original policy objectives are recurrent. The EU also experiences significant difficulties in establishing the real impact of EU policies at a national level, due [...] to the sheer complexity of the multi-level interactions that inform the EU integration process. ${ }^{46}$

Clearly, in such a complex and intricate system of governance involving national, subnational, and supranational authorities, successfully carrying out common objectives through EU policy becomes difficult. Moreover, when the real power to actually implement policy lies within the hands of member states who may not always see eye-to-eye with one another or the EU, and may very well have differing national interests, the efficacy of common policy is uncertain. Indeed, in a system such as this, member states are often reluctant to outsource their control to the EU as it illustrates a potential transfer of sovereignty and accompanying loss of power of national authority. ${ }^{47}$ Likewise, even when the EU demonstrates its competence in dealing with issues, this may have no influence over EU unity. Member states are unlikely to cooperate if national authorities perceive the EU position as divergent from their own preferences or consider it unbeneficial to cooperate on the premise of a common European objective. ${ }^{48}$

EU institutions and treaties themselves may have also lessened the capability of multi-level governance to flourish within the European region. Throughout the EU's evolution, member states have constructed numerous treaties which they later amended to expand the scope of the EU, thereby significantly altering the institutional and procedural framework of the Union. These revisions have been subject to a threefold process which has ultimately limited the power of EU institutions, yet at the same time expanded the institutional involvement. As defined by Maurer, Mittag, and Wessels, this process is as follows: an accentuation of absolute intergovernmentalism's failure to produce effective measures within the EU by highlighting the dilemma of free-riding that arises during cooperation without supranational arbitration; this is followed by a collective search for an organizational framework that includes the institutions of the EU as brokers of policy areas in order to establish a form of 'rationalized intergovernmentalism'; finally, governments are forced to commit themselves to qualified majority voting and to revisit the treaties to create an efficient set of rules with a stronger role for supranational bodies by acquiescing some of their sovereignty. ${ }^{49}$ The process of formulating EU treaties places an emphasis on supranational procedures and delegating authority to an EU set of rules. Unfortunately, it situates policy largely within the intergovernmental pillars of the Union, creating ambiguous policy fields and raising the potential

\footnotetext{
${ }^{46}$ Simona Milio, From Policy to Implementation in the European Union: The Challenge of a Multi-Level Governance System (New York: I.B. Tauris Publishers, 2010), 4.

${ }^{47}$ Louise G. van Schaik, "EU Competence: A Precondition for EU Unity?" in EU Effectiveness and Unity in Multilateral Negotiations (New York: Palgrave Macmillan, 2013), 56.

${ }^{48}$ Ibid, 69.

${ }^{49}$ Andreas Maurer, Jurgen Mittag, and Wolfgang Wessels, "National Systems' Adaptation to the EU System: Trends, Offers, and Constraints," in Linking EU and National Governance, edited by Beate Kohler-Koch (New York: Oxford University Press, 2003), 58-59.
} 
for conflict between the actors involved. ${ }^{50}$ In other words, treaties have actually separated the competencies of member states and EU institutions rather than consolidating them. Ultimately this challenges the project of European integration and, more importantly, institutionally restrains the ability of multi-level governance to resolve conflict.

When analyzing the issues of immigration and asylum crises more specifically, the same strains on an EU-led policy can be observed. The European policy area of 'Freedom, Justice, and Security' promoted by Justice and home affairs (JHA), has incurred a considerable emphasis of cooperation between member states. In particular, JHA encourages states to strengthen their competencies regarding common policies on immigration and asylum seekers, management of external EU borders, best practices in national policing, and an elaboration of common standards. ${ }^{51}$ However, as Christina Boswell states, the measures pursued by the JHA in realizing their objectives have not yet created an established pattern of cooperation, leaving the EU hard-pressed to facilitate the attainment of these policy goals and resolve the crises associated with emigration. ${ }^{52}$ In addition, Christopher Bickerton points out that the JHA's compromise of navigating between intensive intergovernmental efforts and consolidating authority in supranational entities has spurred a debate surrounding sovereignty, separating member states and the EU even further. ${ }^{53}$ This would suggest that the very institution (JHA) entrusted to facilitate cooperation between member states and the EU in resolving immigration issues, may in fact be prohibiting these common policies from realizing their objectives. Ultimately it may prevent the introduction of a pan-European solution to asylum-seekers and the refugee crisis.

\section{Initial Recommendations for Multi-Level Governance}

Both internationally, and internally within the EU it has been stressed that the only way to resolve the current refugee crisis is through a united European response; anything less is simple inadequate.$^{54}$ Revisiting the theory of multi-level governance, which states that authority becomes decentralized in national governments to be reallocated to subnational and supranational entities, it is clear that national governments seem to wield considerable authority with regard to asylum policy. Member states are able to repeatedly ignore their supranational counterpart and bypass the common policies which they agreed to when they ratified the treaties of the EU. Shifting to a system characterized by federalism would mitigate these issues and would offer the best chance for abating

\footnotetext{
${ }^{50}$ Andreas Maurer, Jurgen Mittag, and Wolfgang Wessels, "National Systems' Adaptation to the EU System: Trends, Offers, and Constraints," in Linking EU and National Governance, edited by Beate Kohler-Koch (New York: Oxford University Press, 2003), 60.

${ }^{51}$ Christopher J. Bickerton, "Europe's Compromising Union," in European Integration: From Nation-States to Member States (Oxford: Oxford University Press, 2012): 38.

${ }^{52}$ Boswell, "The "external dimension,"” 620.

${ }^{53}$ Bickerton would agree with Boswell that the JHA seems to complicate efforts toward the asylum crisis rather than consolidate them. Importantly however, he adds that the concerns of national governments over their sovereignty within the multi-level model lie behind the complexity of the JHA domain, thereby reducing the potential to solving asylum crises. (Bickerton 2012: 39).

${ }^{54}$ See the Human Rights Watch's "World Report 2016." They comment critically on the European Union's responses to the refugee crises as inadequate and falling short of any sort of resolution. In particular, the report cites disjointed efforts and the attempts of EU member states to shift responsibility onto external countries as major reasons for the continual failure to reach a resolution. Internally, European and national officials alike have commented on the need for a comprehensive and cooperative effort (2016).
} 
the political and social disintegration generated by this crisis. In order to fix the EU's broken asylum system, there are three key changes that can increase the EU's decision-making power and ultimately its role in solving the refugee crisis: strict implementation and enforcement of EU asylum laws by the European Commission; amending the Dublin Regulation; and establishing an EU-wide asylum status and a centralized EU agency.

Implementing and enforcing EU asylum laws: Looking back on EU asylum policies immediately following WWII, it is evident that the EU can be collectively efficient in employing universal regulations to dealing with emigration. The current EU asylum policy, although showing promise to integrate EU institutions into higher roles of importance, has largely been seen as a failure of the EU to instigate a more liberal approach. It has been criticized as having idealized expectations about member states' willingness to accept liberal values and as being ineffective at empowering the EU to maneuver between divergent interests to align them with EU-wide policy. ${ }^{55}$ The asylum laws put in place through several key treaties must be harmonized across all national governments and strictly enforced by the EU. The implementation could be supervised by the European Asylum Support Office (EASO) ensuring that national executives upheld their duty to implement EU laws properly. ${ }^{56}$

Amend the Dublin Regulation: The EU needs to increase the burden-sharing of states so as to eliminate the free-riding of those who remain idle and purposely avoid extending their help to refugees. This becomes possible with the Dublin Regulation. Asylum-seekers are not allowed to transfer their application beyond the country they originally arrived in, and, considering that a disproportionate amount of asylum-seekers arrive in only a handful of countries, those that are cushioned between states with coastal borders evade the brunt of responsibility. Modifying the Dublin system would be a large step toward shifting responsibility sharing to a heightened multilevel governance model. Member states would no longer be able to avoid the crisis as they would become equally responsible under EU law to protect the rights of refugees. Furthermore, reallocating the responsibility and power from national executives would consolidate much of the authority to govern the situation in the hands of the EU.

\section{EU-wide asylum status and centralized EU agency}

Creating a uniform asylum status, thereby eliminating the different definitions of emigration, would simplify the procedure of asylum application. This would ideally mitigate the harsh shelter conditions experienced by many due to their ethnic or religious background, and the malpractice of several member states. Although this would be a difficult task, as there are so many applicants, some commentators have suggested the creation of a centralized EU agency that would oversee a common asylum code and decision process would expedite the process while

\footnotetext{
${ }^{55}$ Christina Boswell and Andrew Geddes, "Asylum," in Migration and Mobility in the European Union (New York: Palgrave Macmillan, 2011): 161-162.

${ }^{56}$ Bakowski et al. discuss the potential to drastically increase coordination and cooperation if the EU were to formally involve one of its institutive branches in the overseeing of common migration policy. They estimate that with the introduction of the EASO into the process, states would be compelled and even forced into applying EU standards and rules which would ultimately increase the coherence between member states in resolving the crisis $(2015,4)$.
} 
simultaneously determining responsibilities of member states. ${ }^{57}$ Again, this would formalize decision-making power in an EU institution and would allow the EU itself to regulate the equal treatment of asylum-seekers throughout the Union.

Taking these modifications together, it creates a policy field in which the multi-level system embodies federalism at its core. Currently, the EU does not fulfill the federal criterion of having formal sovereignty, and is therefore not considered a federation because authority primarily rests with the member states. ${ }^{58}$ This relatively limited share of sovereignty leaves the EU with hardly any power to directly implement common European rules and policies. The EU's lack of autonomy makes it completely reliant on member states to implement policy as they hold the stronger position in decision-making and policy implementation. ${ }^{59}$ In sum, decentralizing the sovereignty of member states and concentrating authority in the hands of the EU to deal with asylum policy is a pragmatic option that should be fiercely pursued by EU executives and member states alike.

\section{Conclusion}

The state-centric approaches that have defined the European response to the current refugee crisis have, for the most part, failed in their efficacy at ending the dilemma. This crisis has been the ultimate test of European integration and EU solidarity, significantly challenging the viability of both. By applying the theories of state-centric and multi-level governance models of integration, it was shown how the intergovernmental responses currently pursued by member states have actually exacerbated the crisis. It also highlighted the necessity of restructuring the response into an elevated multi-level governance system with the EU at the forefront. Using both historical and contemporary examples of state-centric failure, the potential successfulness and the dire need for an EU that closer resembles federalism, rather than a collection of 'kingdoms,' was stressed. Through several initial recommendations, it was argued that in practice, the EU would adopt a stronger role in the crisis by empowering central EU institutions. This would take the form of a stronger central authority that would enforce common asylum policies and statuses across the member states. In other words, national governments would be less able to pursue either isolationist or uncooperative approaches, obliging them to a follow a comprehensive and cohesive framework. Although the scope of this paper was limited to asylum policy and, as such, did not argue for a complete federalist overhaul of the EU, it showed how the transition to a federalist approach to the refugee crisis could be an effective resolution. Conversely, if it continues to fail in its attempts at resolving the crisis, it is only bound to worsen, leading to the displacement, neglect, and death of thousands more refugees along with increasing sentiments of discontent between member states. The EU's vulnerable project of integration, let alone its survival, now maybe more than ever, heavily depends on the shift to a system of multi-level governance.

\footnotetext{
${ }^{57}$ Bakowski et al., "EU migratory challenge," 5.

${ }^{58}$ Ingeborg Tommel, "The European Union - A Federation Sui Generis?" in The EU and Federalism: Polities and Policies Compared, edited by Finn Laursen (Burlington: Ashgate Publishing Company, 2011), 43.

${ }^{59} \mathrm{Ibid}, 45$.
} 


\section{Bibliography}

Baker, Paul and Costas Gabrielatos. "Fleeing, Sneaking, Flooding." Journal of English Linguistics 36.1 (2008): 5-38. doi: 10.1177/0075424207311247.

Bakowski, Piotr, Eva-Maria Poptcheva, and Detelin Ivanov. "EU migratory challenge: Possible responses to the refugee crisis." European Parliament Research Service, September 2015.

http://www.europarl.europa.eu/RegData/etudes/BRIE/2015/568312/EPRS BRI(2 015)568312 EN.pdf.

Bendel, Petra. "Asylum and Migration Policy." In Policies within the EU Multi-Level System. Edited by Hubert Heinelt and Michele Knodt. Germany: Nomos, 2011. 371-385.

Bickerton, Christopher J. “Europe’s Compromising Union.” In European Integration: From Nation-States to Member States. Oxford: Oxford University Press, 2012. 21-50.

Boswell, Christina. "The 'external dimension' of EU immigration and asylum policy." International Affairs 79, no. 3 (2003): 619-638.

Boswell, Christina. "Values and the Asylum Crisis." International Affairs 76, no. 3 (2000): 537-557. http://www.jstor.org/stable/2625953.

Boswell, Christina, and Andrew Geddes. "Asylum." In Migration and Mobility in the European Union. New York: Palgrave Macmillan, 2011. 150-175.

Boswell, Christina, and Andrew Geddes. "Studying Migration and Mobility in the European Union." In Migration and Mobility in the European Union. New York: Palgrave Macmillan, 2011. 1-20.

Brekke, Jan-Paul and Grete Brochmann. "Stuck in Transit: Secondary Migration of Asylum Seekers in Europe, National Differences, and the Dublin Regulation." Journal of Refugee Studies 28, no. 2 (2015): 145-162. doi: 10.1093/jrs/feu028.

Calamur, Krishnadev. "The Steady Trickle of Refugee Deaths in the Mediterranean." The Atlantic. February 8, 2016. Web. Accessed March 11, 2016. http://www.theatlantic.com/international/archive/2016/02/refugeesdrowning/460419/.

Dyer, Gwynne. "Europe's Refugee Crisis: The Good, the Bad and the Ugly." The Sydney Morning Herald. September 3, 2015. Web. Accessed December 1, 2015. http://www.smh.com.au/comment/eu-response-to-migrant-crisis-ranges-fromgenerosity-to-panic-20150903-gje39e.html.

Erbsen, Allan. "Horizontal Federalism." Minnesota Law Review 93.2 (2008-2009): 493-584.

Farrer, Martin. "Yanis Varoufakis: Europe is being broken apart by the refugee crisis." theguardian. November 23, 2015. Web. Accessed November 29, 2015. http://www.theguardian.com/world/2015/nov/23/yanis-varoufakis-europe-isbeing-broken-apart-by-refugee-crisis.

Graham, Luke. "How Europeans have reacted to migrant crisis." CNBC. September 8, 2015. http://www.cnbc.com/2015/09/08/how-europeans-have-reacted-to-migrantcrisis.html.

Guild, Elspeth et al. "The 2015 Refugee Crisis in the European Union." Center for European Policy Studies no. 332. September 2015. Web. Accessed November 29, 2015. https://www.ceps.eu/system/files/CEPS\%20PB332\%20Refugee $\% 20$ Crisis $\% 20 \mathrm{in} \%$ 20EU 0.pdf. 
Human Rights Watch. “European Union: Refugee Responses Fall Short.” World Report 2016. January 27, 2016. Accessed February 7, 2016.

https://www.hrw.org/news/2016/01/27/european-union-refugee-response-fallsshort.

Kaelin, Lukas. "Europe's Broken Borders." Foreign Affairs. September 2, 2015. Accessed November 30, 2015. http://www.foreignaffairs.com/articles/westerneurope/2015-09-02/europes=broken-borders.

Kern, Kristine, and Harriet Bulkeley. "Cities, Europeanization and Multi-Level Governance: Governing Climate Change through Transnational Municipal Networks*." Journal of Common Market Studies 47, no. 2 (2009): 309-332.

Legrain, Philippe. "The Disintegration of Europe." Social Europe. October 20, 2015. Web. Accessed December 1, 2015. http://www.socialeurope.eu/2015/10/thedisintegration-of-europe/.

Marks, Gary, Liesbet Hooghe, and Kermit Blank. "European Integration from the 1980s: State-Centric v. Multi-level Governance." Journal of Common Market Studies 34, no. 3 (1996): 341-378. DOI: 10.1111/j.1468-5965.1996.tb00577.x.

Maurer, Andreas, Jurgen Mittag, and Wolfgang Wessels. "National Systems' Adaptation to the EU System: Trends, Offers, and Constraints." In Linking EU and National Governance. Edited by Beate Kohler-Koch. New York: Oxford University Press, 2003. 53-81.

McGreal, Chris. "Donald Tusk defends European response to 'unprecedented' refugee crisis." theguardian. September 29, 2015. Web. Accessed November 30, 2015. http://www.theguardian.com/world/2015/sep/29/donald-tusk-defendseuropean-values-united-nations.

Milio, Simona. From Policy to Implementation in the European Union: The Challenge of a Multi-Level Governance System. New York: I.B. Tauris Publishers, 2010.

"Migrant Crisis: Migration to Europe explained in several charts." BBC News. March 4, 2016. Web. Accessed March 13, 2016. http://www.bbc.com/news/world-europe34131911.

Ostrand, Nicole. "The Syrian Refugee Crisis: A Comparison of Responses by Germany, Sweden, the United Kingdom, and the United States." Journal of Migration and Human Security 3, no. 3 (2015): 255-279.

Plucinska, Joanna. "The Paris Attacks Have Put Europe's Refugee Crisis Under Renewed Scrutiny." Time. November 16, 2015. Web. Accessed December 1, 2015. http://time.com/4114009/paris-attacks-migrant-crisis-refugees-eu/.

"Reactions to Refugee Crisis May Violate States' International Legal Obligations." International Justice Resource Center. November 25, 2015. Web. Accessed November 30, 2015. http://www.ijrcenter.org/2015/11/25/reactions-to-refugee-crisis-mayviolate-states-international-legal-obligations/.

Ross, George. "Flight of the Member States." In The European Union and Its Crises: Through the Eyes of the Brussels Elite. New York: Palgrave Macmillan, 2011. 60-73.

Tommel, Ingeborg. “The European Union - A Federation Sui Generis?” In The EU and Federalism: Polities and Policies Compared. Edited by Finn Laursen. Burlington: Ashgate Publishing Company, 2011. 41-56.

UNHCR The UN Refugee Agency. "2015 UNHCR regional operations profile - Europe." UNHCR Global Appeal 2015 Update. 2015. http://www.unhcr.org/5461e5f80.html. 
van Schaik, Louise G. “EU Competence: A Precondition for EU Unity?” In EU Effectiveness and Unity in Multilateral Negotiations. New York: Palgrave Macmillan, 2013. 54-69. 